\title{
The Existence of Indonesian Language in the Digital Era in the Perspective of Philosophy of Science (Axiology)
}

\author{
Aprilia Dewantari; aprilia.dewantari-2020@fib.unair.ac.id ${ }^{1}$ Amrina Rosada Dhuhuriyah; \\ amrina.rosada.dhuhuriyah-2020@fib.unair.ac.id² Tiara Alifia Rahmatika; \\ $\underline{\text { tiara.alifia.rahmatika-2020@ fib.unair.ac.id }}{ }^{3}$
}

Gisela Rose Karita; gisela.mawar.karita-2020@fib.unair.ac.id ${ }^{4}$

Moses Glorino Rumambo Pandin; moses.glorino@fib.unair.ac.id

\section{Corresponding Author}

Moses Glorino Rumambo Pandin; moses.glorino@fib.unair.ac.id

Faculty of Humanities, Airlangga University

Campus B Jl. Airlangga 4-6 Surabaya, East Java, Indonesia 60286

Tel: 031-5035807. Fax: 031-5035807

\begin{abstract}
Indonesian is the identity of all Indonesian citizens. Language itself is very important for human life. With language, we can communicate with one another, considering that humans are social creatures who cannot live without each other's help. However, the use of language should not be underestimated. The use and pronunciation must be properly understood so that there are no misunderstandings or other unwanted things. The development of the times and globalization have affected the existence of languages that are currently starting to lose their authenticity. One example is the use of slang as a daily word until the authenticity (original word) is slowly forgotten. As well as the use of foreign languages that are more attractive to the millennial generation. The lack of interest of the younger generation in learning linguistic rules is also one of the factors in changing the existence of Indonesian. The background of the research is about the existence of language, especially Indonesian to the changing era. The purpose of writing this paper is to show the public, especially the millennial generation the importance of maintaining the existence of linguistic rules. Because as good citizens we must maintain and preserve our national identity.
\end{abstract}

Keywords: Foreign languages, Indonesian, slang, modern. 


\section{INTRODUCTION}

Language is formed by some rules and also the scheme that should not be violated so as not to cause interference in the communication that occurs. Kridalaksana and Djoko K. (in Chaer, 2014: 32) say that language is a scheme of despotic sound patterns used by an individual of social groups to work together, communicate, and also identify themselves. Communication can run smoothly when the recipient and sender of the language must master the language. Language is an important thing used to communicate by the people who use it. What makes a good language is when the language developed a system in it, or we can say it is a set of rules that are must be obeyed by the people. Language's main function is basically as a way of communication as well as a way of adaptation.

In philosophy, language is a limitless medium that brings everything capable of being contained in the field of human understanding. Therefore, language can continue to develop because it is flexible and without boundaries. It is not unusual if as the times change, the use of language also changes. So, sentence structure in a language is a crucial thing that must be maintained its authenticity. The development of the times is one of the factors that change the authenticity of the Indonesian language. Advances in technology have proven to be very beneficial for the convenience of human life, but that does not mean that these rights do not have a negative impact.

In addition, Indonesian is the national language and the official language for the Indonesian people. Indonesia is also a communication tool and a unifying tool for the nation. As time goes by, the language also develops according to the times. One of them is in the digitalization era as it is today, now many foreign languages are used in the digitalization era besides Indonesian. Having the ability to speak a foreign language is one of the added values in the digitalization era, this is because almost most of the existing technology uses English for its application, and also the ability to speak foreign languages can increase competitiveness and play a role in global life. However, with the widespread use of foreign languages, especially English, this excess has shifted the use for the correct way of Bahasa Indonesia in the daily lives of Indonesian people. 


\section{RESEARCH METHODS}

In compiling scientific papers to produce a good presentation, we use several research methods, namely the survey research method by distributing questionnaires and conducting interviews with several of our research targets. Distributing questionnaires and conducting interviews are useful to find out what people think about our topic. Second, we use qualitative research methods, namely by multiplying readings on journals related to our topic. It is intended that we have a view and make some of these readings as a reference for the preparation of this scientific paper. Not only that, using qualitative methods also helps us to understand and provide a broader idea related to the topics we take. And finally, we also use the case study method where we add a case that has been experienced by someone and uncover the variables that cause such things to happen. It aims to provide an example to the reader that things like that can happen in this life.

\section{DISCUSSION}

As we know language is one of the important things needed in communicating with other people. There are also many languages, ranging from body language, regional languages to national and international languages. This time the discussion of the language that will be discussed and described in this scientific paper is none other than the language of unity in our motherland, namely Indonesian. The increasingly modern era does not rule out the possibility of having good and bad influences in the country. We also cannot expect the possibility of foreign languages entering our country or even the Indonesian language appearing with its latest version which we usually know as slang. For example, the use of words is starting to increase in slang nowadays such as "gelay" from the word "gak like" which means not to like something. As for the use of the word behind-behind (walikan) typical of Malang City, such as "ngab" means "bang" or "kuy" means "yuk". Another example is the abbreviation of words such as "jamet" namely "Jawa Metal" which is usually used to describe someone who looks tacky in appearance. As for other versions, such as mixing between Indonesian and English, which are famously used by residents around South Jakarta or commonly called the South Jakarta language. This slang is very attractive to young people, so it can be easily spread, assisted by adequate technology in this era. Some people may argue that these changes are normal in this millennial era. However, it should be noted that the role of language is very important for national identity and the interests of its people. In philosophy until there is a 
branch of philosophy of language that focuses on knowledge and investigation of the nature of language, its legal origin, and development.

Mulyana argues (in Sari 2015: 2), slang is a group of words or parlance that have unique, deviant or even contradictory meanings when used by people from certain subcultures. This deviation has given rise to a bad view of language development in this digital era. Changes in the meaning or meaning of the linguistic rules are things that cause differences or nonuniformities in grammar. The linguist, John Searle, classified language into five parts. One of them is expressive, namely the form of expressing feelings such as "sorry" as a form of a request for mistakes made. But in this era, the word sorry already has a different meaning from the original. When they say "sorry sorry ni ye" it means they are mocking something they don't like or can be sarcastic. In the KBBI (Big Indonesian Dictionary) there is meaning of the word snake is an animal with scales, but not necessarily a scaly one called a snake.

We also conducted a google form survey that we distributed; many participants chose to ignore the rules for the correct way of Bahasa Indonesia use when speaking directly. The purpose of this survey is to find out what people are currently interested in in terms of the language rules they use.

\begin{tabular}{|c|c|c|c|}
\hline $\begin{array}{l}\text { TOTAL } \\
\text { PARTICIPANTS: } \\
100\end{array}$ & $\begin{array}{l}\text { Using Indonesian by } \\
\text { paying attention to } \\
\text { spelling and rules }\end{array}$ & $\begin{array}{l}\text { Using Indonesian } \\
\text { irregularly/not } \\
\text { according to } \\
\text { linguistic rules }\end{array}$ & $\begin{array}{l}\text { Not using } \\
\text { Indonesian, } \\
\text { Preferring a foreign } \\
\text { language or regional } \\
\text { language }\end{array}$ \\
\hline & 25 & 65 & 10 \\
\hline
\end{tabular}

25 people still maintain good and correct use of Indonesian, when speaking or in other activities. 65 people choose to use Indonesian irregularly or not in accordance with linguistic rules. Where they still use Indonesian but with additional slang or foreign languages such as English. 10 people do not choose Indonesian and prefer to use a foreign language or regional language. Why is the percentage of using Indonesian language irregularly or not in accordance 
with linguistic rules more chosen? This is because the existence of Indonesian has now been mixed with other languages, especially slang. They think that adding slang or a foreign language when speaking in Indonesian makes it look cool and modern. Even several journals that are widely spread say that the Indonesian language is less attractive to young people today. Why is that? because Indonesian is less ogled by Indonesian people but more ogled by foreign people. Even learning Indonesian at the university level is quite lacking. In some majors, Indonesian is not even made a compulsory subject, but foreign languages are a compulsory subject for students. This shows that the Indonesian people have not even paid attention to their existence by Indonesian people themselves. Most of them think that English must be owned by everyone because it is an international language and has become a necessity in the world of work. The results of this survey can be concluded that it is very clear how people underestimate the rules of their own language. Of course, this is very unfortunate. Young people who should promote the preservation of the nation's language and culture have instead shifted the identity of their own nation's language.

In the digital era, there are also many articles, journals, and even scientific papers that are required to use a foreign language, namely English. It is useful to attract many readers both from within the country and abroad. In addition, with the development of today's language, there are also many uses of slang in everyday life. In essence, this slang can be a play on Indonesian or a mixture of Indonesian and English. Most of the slang users are the younger generation, and ironically most of them cannot speak Indonesian properly. This of course has a negative impact if it continues, this problem will hamper the development of the Indonesian language as an identity for the Indonesian people.

With the development of eras, one of which is the development into the era of digitalization, the development of the Indonesian language seems to be increasingly being displaced by its existence due to the large number of Indonesian people who use foreign languages, especially English as the language used in everyday life. This is one of the consequences of the many applications of English as an international language, most people feel that if they can speak English they are considered cool. Therefore, this is a complex problem, but it cannot be denied that this is due to the development of the era and the times that occur. 


\section{CONCLUSION}

According on the discussion, it can be assumed that language really needs to be used to communicate with each other and in this digital era, many varieties of languages have emerged, one of which is slang. However, according to experts, the existence of slang is something that can deviate because it can give birth to bad views in this digital era. For example, when they say "sorry sorry ni ye" it means they are mocking something they don't like or can be sarcastic. Then at the writing of this paper, to find out what the current people's interest in the language rules they use, a survey was conducted and the results were that 25 people still maintained the use of good and correct Indonesian, when speaking and other activities, 65 people chose to use Indonesian irregularly. or not in accordance with linguistic rules and 10 people do not choose Indonesian and prefer to use a foreign language or regional language. This is because the existence of Indonesian has now been mixed with other languages, especially slang.

\section{SUGGESTION}

Even though the author expects perfection in the making of this paper, but in real life, we are still facing many imperfections that we the author have to improve. Because it has happened as the effects of lacking acknowledgment of the author. Hence, constructive criticism or advice and suggestions from the readers are highly expected as evaluation material for the future. 


\section{REFERENCES}

Wijana, Putu, Dewa, I. November 2020. "Pragmatik Sebagai Penangkal Hoaks dan Peran Ilmuwan Bahasa di Era Digital” dalam Jalabahasa, Vol. 16, No. 2. Fakultas Ilmu Budaya Universitas Gadjah Mada.

Febiana, Asprilia, Sudaryanto. 2019. "Pembinaan Bahasa Indonesia: Bagaimana Strateginya di Era Digital?" dalam Jurnalistrendi: Jurnal Linguistik, Sastra, dan Pendidikan Vol. 4, No. 1. Universitas Ahmad Dahlan.

Saputro, Yusuf, Muhammad. 3 Agustus 2019. "Perencanaan Bahasa Indonesia di Era Digital Pada Generasi Milenial" dalam Pesona Prosiding Pekan Seminar Nasional Pendidikan Bahasa dan Sastra Indonesia Vol. 2, No. 1. Jakarta: Program Studi Pendidikan Bahasa dan Sastra Indonesia Universitas Muhammadiyah.

Tri, Dekha, Desy. Maret 2019. "Eksistensi Bahasa Indonesia Pada Generasi Milenial di Era Industri” dalam Bahastra: Jurnal Pendidikan Bahasa dan Sastra Indonesia Vol. 3, No. 2. Fakultas Keguruan dan Ilmu Pendidikan Universitas Bung Hatta.

Riyanto, Robby. 2021. "Filsafat Digital Integral: Reformulasi Program Literasi Digital Nasional di Era Pandemi Covid-19 di Indonesia" dalam Fikrah: Jurnal Ilmu Aqidah dan Studi Keagamaan Vol. 9, No. 2. Kudus: Prodi Aqidah dan Filsafat Islam IAIN.

Sihotang, Kasdin. 2019. Berpikir Kritis Kecakapan Hidup di Era Digital. Sleman: PT Kanisius.

I, Senafi. Juni 2019. "Hoax Dalam Perspektif Filsafat" dalam Prosiding Seminar Nasional Filsafat. Denpasar: IHDN PRESS.

Wigunawati, Eustalia. Maret 2019. "Filsafat Pendidikan Driyarkara Dalam Menjawab Tantangan Era Industri” dalam Jurnal Pendidikan Agama Kristen Regula Fidei, Vol. 4, No. 1. (hlm 57-59). Program Studi Bimbingan dan Konseling, Universitas Kristen Indonesia.

Aziz Rachdian, Muhammad. September 2021. "Dialektika Hegel (Tesis-AntitesisSintesis) dalam Etika dan Filsafat Berkomunikasi Era Kontemporer" dalam Jurnal Komunikasi Vol. 12, No. 2. Jakarta: Universitas Indonesia.

Taufik, Hilda, Pujo. 2019. "Pengutamaan Bahasa Indonesia: suatu langkah aplikatif" dalam El Banar: Jurnal pendidikan dan pengajaran Vol. 2 No, 1. Jakarta: Universitas Indraprasta PGRI.

Nur, Suci. 2021. "Faktor- faktor perubahan gaya hidup masyarakat di era globalisasi: studi deskriptif tentang perilaku dan gaya hidup remaja di kampung rancajigang desa padamulya kecamatan majalaya kabupaten bandung" dalam Diploma thesis. Bandung: UIN sunan gunung jati.

Syafryadin, Wisma, Irma. 2019. "Interferensi Bahasa Indonesia terhadap Kemampuan Berbicara Bahasa Inggris Mahasiswa Universitas Bengkulu" dalam Prosiding Seminar Nasional Bulan Bahasa. Jurusan Pendidikan Bahasa dan Seni, Universitas Bengkulu.

Prasetyo, Teguh. 2021. "Analisis berpikir kreatif mahasiswa dalam pembelajaran daring bahasa indonesia" dalam Jurnal Ilmu Pendidikan Vol. 3. No, 6. Faculty of Education University of Pahlawan tuanku tambusai.

Rohmah, Nur, Sari. Januari 2019. "Eksistensi Bahasa Indonesia dan Bahasa Inggris dalam Ilmu Pengetahuan di Era Globalisasi” dalam Jurnal 1 Pendidikan. Surakarta: Universitas Sebelas Maret. 
Azizah, Rif'at, Auva. September 2019. "Penggunaan Bahasa Indonesia dan Bahasa Gaul di Kalangan Remaja" dalam jurnal scripta: jurnal pembelajaran bahasa dan sastra indonesia. Yogyakarta: Universitas Pembangunan Nasional.

Susanti, Wiwik. Januari 2019. "Eksistensi Bahasa Indonesia Dalam Bidang Ilmu Pengetahuan di Era Globalisasi” dalam Jurnal Pendidikan. Surakarta: Universitas Sebelas Maret.

Dewi, Puspa, A. Januari 2019. "Potret Penggunaan Bahasa Remaja Terhadap Eksistensi Bahasa Indonesia di Kalangan Mahasiswa" dalam Jurnal Pendidikan. Surakarta: Universitas Sebelas Maret.

Reka, Sajdah, Ayu. 2019. "Perspektif Generasi Milenial Terhadap Eksistensi Bahasa Indonesia di Media Sosial" dalam Parole: Jurnal Pendidikan Bahasa dan Sastra Indonesia Vol. 1 No, 2. Bandung.

Annisa, P. Januari 2019. "Pengaruh Bahasa Asing terhadap Bahasa Indonesia di Tengah Arus Globalisasi" dalam Jurnal Pendidikan. Surakarta: Universitas Sebelas Maret.

Yuliana, N. M. A. Januari 2019. "Eksistensi Bahasa Indonesia di Samping Bahasa Inggris" dalam INA-Rxiv Papers. Surakarta: Universitas Sebelas Maret.

Widowati, D. F. Januari 2019. "Eksistensi Bahasa Indonesia Dalam Menunjang Ilmu Pengetahuan di Tengah Maraknya Penggunaan Bahasa Asing di Era Globalisasi” dalam INA-Rxiv Papers. Surakarta: Universitas Sebelas Maret.

Pertiwi, Chintami, Budi. Januari 2019. "Eksistensi Bahasa Indonesia Sebagai Bahasa Nasional Dalam Upaya Menghadapi Generasi Milenial" dalam INA-Rxiv Papers. Surakarta: Universitas Sebelas Maret.

Nurpratiwiningsih, Laelia dan Moh. Jauharul Maknun. Februari 2020. "Pengaruh Globalisasi Terhadap Penggunaan Bahasa Indonesia Bagi Masyarakat" dalam Jurnal Ilmiah KONTEKSTUAL, Vol. 1, No. 02. Fakultas Keguruan dan Ilmu Pendidikan, Brebes: Universitas Muhadi Setiabudi.

Febrianti, Yenni, F. Juli 2021. "Penggunaan Bahasa Gaul Terhadap Eksistensi Bahasa Indonesia Pada Masyarakat" dalam Jurnal Ilmu Pendidikan, Vol. 2, No. 1. Medan. Universitas Muslim Nusantara Al Washliyah.

Manurung, Eunike, dan Miftah R., dan Fitriani L. 2021 "Eksistensi Penggunaan Bahasa Indonesia di Kalangan Generasi Muda Pada Masa Pandemi COVID-19 dan Era Globalisasi” dalam Dialektika, Vol. 8, No. 1. Medan: Universitas Negeri Medan.

Puspita, Ayunda, Riska dan Hafidz Rosyidiana. 2020. "Eksistensi Kebakuan Bahasa Indonesia dalam Karya Tulis Mahasiswa" dalam BELAJAR BAHASA, Vol. 5, No. 2. Ponorogo: Institut Agama Islam Negeri Ponorogo.

Safika, Novy, Dwy. Januari 2020. "Pengaruh Pemakaian Bahasa Gaul terhadap Kemampuan Berbahasa Indonesia Remaja” dalam INA-Rxiv Papers. Surakarta: Universitas Sebelas Maret.

Kase, Sarjan. Februari 2019. "Bahasa Indonesia dalam Eksistensi Masyarakat Ekonomi ASEAN" dalam Jurnal Ideas, Vol. 5, No. 1. Gorontalo

Ma'rufah, Lifthihah, Anis dan Meilan Arsanti. 2021. "Eksistensi Bahasa Indonesia di Universitas Luar Negeri” dalam Jurnal Pendidikan Bahasa Indonesia, Vol. 9, No. 1. Semarang: FKIP Universitas Islam Sultan Agung.

Kusumaningrum, K. Januari 2019. "Pengaruh Pengajaran Bahasa Indonesia dan Bahasa Inggris dalam Dunia Pendidikan di Era Globalisasi" dalam INA-Rxiv Papers. Surakarta: Fakultas Keguruan dan Ilmu Pendidikan, Universitas Sebelas Maret. 
Devianty, R. 2020. "Eksistensi Bahasa Indonesia pada Masa Pandemi” dalam

Nizhamiyah, Vol. 10, No. 2. Medan: Fakultas Ilmu Tarbiyah dan Keguruan,

Universitas Islam Negeri Sumatera Utara Medan.

Wibowo, Bagus, J. 2019. "Penggunaan Bahasa Asing Terhadap Jati Diri Bahasa Indonesia di Kalangan Mahasiswa" dalam INA-Rxiv Papers. Surakarta: Fakultas Keguruan dan Ilmu Pendidikan, Universitas Sebelas Maret.

Saputro, Yusuf, C. 2019. "Pengutamaan Bahasa Indonesia Sebagai Bahasa Nasional Dalam Menyongsong Era Generasi Milenial” dalam INA-Rxiv Papers. Surakarta: Fakultas Keguruan dan Ilmu Pendidikan, Universitas Sebelas Maret.

Risqi, Annisa. 2019. "Peran Bahasa Inggris Terhadap Perkembangan Bahasa Indonesia dan Pendidikan di Indonesia" dalam INA-Rxiv Papers. Surakarta: Fakultas Keguruan dan Ilmu Pendidikan, Universitas Sebelas Maret.

Widyawati, Susi. 2019. "Peran Bahasa Indonesia Sebagai Penghela Ilmu Pengetahuan di Era Globalisasi” dalam INA-Rxiv Papers. Surakarta: Fakultas Keguruan dan Ilmu Pendidikan, Universitas Sebelas Maret.

Firadussi, Ade L. W. 2019. "Peran Bahasa Indonesia dan Bahasa Inggris pada Perkembangan Ilmu Pengetahuan di Era Global" dalam INA-Rxiv Papers . Surakarta: Fakultas Keguruan dan Ilmu Pendidikan, Universitas Sebelas Maret.

Wirahyuni, Kadek. 2019. "Penilaian Kesalahan Berbahasa Indonesia yang Baik dan Benar Dalam Konteks Sosial-Masyarakat di Ruang Publik" dalam JPPSH, Vol. 3, No. 1. Bali: Universitas Pendidikan Ganesha.

Susanti, D. D. 2019. "Peran Dua Bahasa dalam Ilmu Pengetahuan di Era Global: Bahasa Indonesia dan Bahasa Inggris" dalam INA-Rxiv Papers. Surakarta: Fakultas Keguruan dan Ilmu Pendidikan, Universitas Sebelas Maret.

Ningsih, Ayu N. M. 2019. "Penggunaan Bahasa Indonesia dan Bahasa Inggris dalam Menunjang Ilmu Pengetahuan di Era Global” dalam INA-Rxiv Papers. Surakarta: Fakultas Keguruan dan Ilmu Pendidikan, Universitas Sebelas Maret.

Jazeri, M., dan Turrofah, I. 2020. "Membangun Karakter Bangsa Melalui Pembelajaran Bahasa Indonesia" dalam GHANCARAN: Jurnal Pendidikan Bahasa dan Sastra Indonesia. Tulungagung: Institut Agama Islam Negeri Tulungagung.

Nurahman, Alifiah. 2020. "The Influence of Slang on The Use of Indonesia at SMP Nusantara Palangkaraya Student in 2020" dalam jurnal pendidikan Vol. 21 No.2. Palangkaraya: Universitas Palangka Raya

Franesti, Dita. 2021. "Eksistensi Penggunaan Bahasa Indonesia Yang Baku Di Kalangan Remaja" dalam Jurnal Bahasa, Sastra, Dan Pembelajarannya Di Era Berkelimpahan. Yogyakarta: Universitas Ahmad Dahlan

Denafri B, Washadi. 2020. "Kesalahan Pemakaian Bahasa Indonesia Media Luar Ruang Di Kota Tangerang Selatan" dalam Journal Language and Literature Vol. 6 No. 2. Universitas Pamulang.

Yoga, Salman. 2019. "Perubahan Sosial Budaya Masyarakat Indonesia dan Perkembangan Teknologi Komunikasi” dalam Jurnal AL BAYAN: Media kajian dan pengembangan ilmu dakwah Vol. 24, No.1. Banda Aceh: Faculty of Da'wah and Communication.

Wati U, Rijal S, Hanum S. Januari 2020. "Variasi Bahasa Pada Mahasiswa Perantau Di Fakultas Ilmu Budaya Universitas Mulawarman: Kajian Sosiolinguistik" dalam Ilmu Budaya: Jurnal Bahasa, Sastra, Seni dan Budaya Vol. 4 No. 1. Universitas Mulawarman. 
Handoko P, Fahmi N, Kurniawan Y, Artating H, Sinaga S. September 2019. "Potensi

Pengembangan Bahasa Indonesia menjadi Bahasa Internasional" dalam Scilit: Jurnal Bahasa Indonesia bagi Penutur Asing Vol 1 (hlm 22-29).

Tiara, Noor F. 2021. "Upaya Diplomasi Kebudayaan KBRI Seoul Dalam Pengembangan Bahasa Indonesia Di Korea Selatan" dalam Institutional Repository. Malang: Universitas Muhammadiyah Malang.

Winata T. N, Jasril. 2021. "Eksistensi Bahasa Indonesia Di Sekolah Menengah Atas" dalam Deiksis: Jurnal Pendidikan Bahasa dan Sastra Indonesia Vol. 8 No. 1.

Oktaviani A. S. Dewi A. D. Juni 2021. "Keberadaan Integritas Bangsa Indonesia di Tengah Derasnya Globalisasi dan Modernisasi di Kalangan Remaja” dalam Jurnal Pendidikan Kewarganegaraan Vol. 5 No. 1. Pontianak: IKIP PGRI Pontianak.

Paida, Andi. 2021. "Interferensi Bahasa Manggarai terhadap Penggunaan Bahasa Indonesia dalam Berkomunikasi Siswa SMA Saribuana Makassar" dalam Jurnal Studi Guru dan Pembelajaran Vol. 4. No. 3. Makassar: Universitas Muhammadiyah Makassar.

Suci, Cita A. N. 2021. "Faktor faktor Perubahan Gaya Hidup Masyarakat di Era Globalisasi: Studi Deskriptif Tentang Perilaku dan Gaya Hidup Remaja di Kampung Rancajigang Desa Padamulya Kecamatan Majalaya Kabupaten Bandung" dalam Digital Library. Bandung: UIN Sunan Gunung Djati.

Priambudi, Wigih. 2021. "Pengaruh Sikap Berbahasa Indonesia di Lingkungan Keluarga Terhadap Keterampilan Berpidato Siswa Kelas IX SMPN 8 Kota Cirebon" dalam IAIN SYEKH NURJATI CIREBON Repository. Cirebon: IAIN Syekh Nurjati.

Hetilaniar. 2021. "Implementasi Literasi Digital Dalam Pembelajaran Bahasa Indonesia Berbasis Kearifan Lokal" dalam Prosiding Seminar Nasional. Universitas PGRI Palembang.

Suci, Ningrum A. November 2021. "Pengembangan Media Pembelajaran Bahasa Indonesia Berbasis Multimedia Interaktif Articulates Storyline Untuk Peserta Didik Kelas III SD/MI” dalam Repository UIN Raden Intan. Lampung: UIN Raden Intan.

Mujianto G, Sudjadil. April 2021. "Tipe Modifikasi Fonem Kata Serapan Asing ke Dalam Bahasa Indonesia pada Surat Kabar Online Berbahasa Indonesia" dalam Kembara: Jurnal Keilmuan Bahasa, Sastra dan Pengajarannya Vol. 7 No 1. Malang: Universitas Muhammadiyah Malang.

Sari, Yunita. Agustus 2020. "Kesalahan Penggunaan Bahasa Indonesia bagi Mahasiswa BIPA di Universitas Negeri Surabaya: Kajian Ragam Bahasa Tulis. Skripsi Thesis, Universitas Airlangga" dalam Repository Universitas Airlangga.

Hakim, Tristanty, Pandin. 2021. "Digital Literacy Prominence at Digital Era from The Perspective of Philosophy of Value (Axiology)" dalam Prepints. Surabaya: Universitas Airlangga.

Rahmawati, Nuzulul. Oktober 2019. Ekspresi Bahasa Nilai Sopan Santun Cerminan Budaya Jawa Pada Masyarakat Arek Surabaya: Kajian Etnolinguistik skripsi thesis, Universitas Airlangga” dalam Repository Universitas Airlangga.

Santiula T, Tribuana R, Putri A, Salwa A, Pandin G. 2021. "Challenge, Roles, And Axiology of Indonesian Digital Literacy During the Pandemic" dalam Preprints. Surabaya: Universitas Airlangga.

Iftitah, Irvana. 2019. "Semantic Categories in The Abstract of ELT (English Language Teaching) Journal at national regional and international level skripsi thesis 
Universitas Airlangga" dalam Repository Universitas Airlangga. Surabaya: Universitas Airlangga. 